\title{
Liselerde Okutulan Türkiye Cumhuriyeti ve Atatürkçülüik Adlı Ders Kitaplarında Çanakkale Savaşları
}

\author{
Yrd. Doç. Dr. Şerafettin ZEYREK*
}

\section{ÖZET}

Bu çalışmada, liselerde okutulan Türkiye Cumhuriyeti ve Atatürkçülük adll ders kitaplarında yer alan Çanakkale Savaşları konusu incelenmiştir. Çalışmanın amacı; I. Dünya Savaşı'nda, Osmanlı'nın son yıllarında ve Türkiye Cumhuriyeti'nin kuruluşunda önemli yer tutan, o yılları ve hâlâ günümüzü etkileyen bir savaşın müfredat programlarında ve derslerde konu olarak nasıl ele alındığını, yazarların bu savaşı nasıl değerlendirdiğini ortaya koymaktır. Ayrıca bazı kitaplardaki konunun içerik yazılışında ve görsellik boyutunda görülen eksiklikleri, UNESCO'nun ve Avrupa Birliği'nin tarih anlayışına uygunluğunu, "olayda küçük düşürme, alaya alma ve hakaret etme” gibi söylemlerin olup olmadığını saptamak, yazımların düzeltilmesini sağlamak ve ders kitapları aracılı̆̆ıyla bu ilişkilerin dostluğu, işbirliğini ve barışın nasıl sağlanabileceği konusunda önerilerde bulunmaktır.

Çalışmada Türk liselerinde okutulmuş ve okutulmakta olan 12 adet ders kitabı incelenmiştir. Bu araştırma literatür incelemesi yöntemiyle yapılmıştır.

Anahtar Sözcükler: Mustafa Kemal, Çanakkale. Çanakkale Savaşları, Gelibolu, Cevat Paşa, Liman Von Sanders, Ian Hamilton, Queen Elizabeth ve Tarih Ders Yaputlart.

- Çanakkale Onsekiz Mart Üniversitesi Eğitim Fakültesi, 054289485 35, szeyrek@comu.edu.tr 


\section{The Çanakkale Wars In The Coursebooks Entitled 'The Turkish Republic and the Atatürk's Principles' Used in the Turkish High Schools.}

\section{ABSTRACT}

In this study, the subject of Çanakkale Wars taking place in the coursebooks 'The Turkish Republic and the Atatürk's Principles' that has been compulsory taught in Turkish high schools has been investigated.

The aim of this study is to reveal those years being considered as important time in the first world war, during the last years of the Ottoman period and in the foundation of Turkish Republic, and also, is to tackle and make explanations about how a war still affecting our present time to be dealt in the curriculums and textbooks and how the writers have evaluated this war. Furthermore, this study examines the adequacy of the content and visual level deficiencies of some books in terms of UNESCO's and European Union's history horizon and determines whether there are humilitiating, mocking, and insulting statements or not, ensures those mistakes to be corrected and provides solutions on how this relationship maintains peace, collaboration, and friendship via textbooks.

In this study, 12 items of course books that have been taought at Turkish Colleges (Lycees) have been gone through. This study has been realized through literature review method.

KEYWORDS: Mustafa Kemal, Çanakkale, Gallipoli, Cevat Pasha, Liman Von Sanders, Ian Hamilton, Çanakkale Wars, Queen Elizabeth and History Cours Books.

Çanakkale Savaşları Çanakkale Boğazı çevresinde kara, deniz, hava, denizaltı ve lağımda olan, yaklaşık dokuz ay süren, Türklerin Fransız, İngiliz, Hintli, Mısırlı, Senagalli, Yahudi ve Anzak denilen insanlara karşı savunma yaptı̆̆ı, iki yüz kırk bine yakın insanın öldügü, bir o kadarının da zarar gördüğü, birçok araç-gerecin yok olduğu ve üzerine türkülerle ağıtların yazıldığı büyük bir olaydır. Başka bir açıdan bakılacak olursa, Mehmetçiğin deyimi ile "Geçilmeyen yer", halkın deyimi ile "Mehmetçiğin ölmeden mezara konulduğu", nişanlı genç kızların yıllarca yas tuttuğu, evli kadınların dul kaldığı ve birçok çocuğun yetim büyüdüğü, başka bir deyişle Türklerin birçok dilden, dinden, her renkten ve çok soydan insanlarla çarpıştı̆̆ı, I. Dünya Savaşı içinde önemli yeri olan bir savaştır.

Çanakkale Savaşları konusu genelde Türkiye Cumhuriyeti İnkılâp Tarihi Dersi içinde yer almıştır. Bu ders, yeni devleti, yeni düzeni korumak, geliştirmek, sürekli kılmak, yeni devletin nasıl kurulduğunu ögretmek ve 
LISELERDE OKUTULAN TÜRKIYE CUMHURIYETI VE ATATÜRKÇÜLÜK .... 709

yakın tarihi belletmek için konulmuştur. Bunları gerçekleştirmek de eğitimle olur. Bu nedenle gençliği devrimin bekçisi yapabilmek ve yukarıda belirtilen amaçları yerine getirebilmek için bu ders, yüksek öğrenime 4 Mart 1934 tarihinde konulmuştur ${ }^{1}$. Yükseköğrenim programında yerini 4 Mart 1934 tarihinde almasına karşın, lise programlarına daha erken girmiştir. Konu, ilk olarak 1924 yılı lise tarih müfredat programının 1927 yılında yapılan ekinin (zeylinin) üçüncü sınıftaki "Asr-1 Hazır Tarihi" bölümünün 32 . maddesindeki "Umumi Harp" başlığında işlenmiştir ${ }^{2} .1931$ y1lı Tarih Dersi Müfredat Programı'nda da konu genel olarak lise üçüncü sınıf için yazdırılan Tarih III adlı kitapta "İmparatorluğun İnhitatı" başlığının Cihan Harbi kısmında yer almıştır". Aynı yıl "Tarih IV Türkiye Cumhuriyeti" diye yine lise üçüncü sınıflara ders konulmuş ve bu ders içerisinde Çanakkale Savaşları konusu yer almamıştır. Yer almamasının nedeni, müfredat programının konularının Çanakkale Savaşlarından sonra gerçekleşen Mondros Ateşkes Antlaşması'ndan başlatılmasıdır. Kısacası, 1938, 1952, 1954, 1959, 1960, 1970, 1974 ve 1976 Türkiye Cumhuriyeti ve İnkılâbı Tarihi programlarında Çanakkale Savaşlarına yer verilmemiştir ${ }^{4}$. Bu anlayış 1981 yılına kadar sürdürülmüştür. Yani bu savaşlar 1981 yılına kadar Devrim Tarihi Dersi müfredat programları içinde değil de, tarih dersi müfredat programları içinde yerini almıştır. Fakat konuların yazımı veya anlatımı 1931 yılından beri ayrı kitaplar biçimindedir. Hem tarih ders kitabında hem de Tarih IV, Türkiye Cumhuriyeti Tarihi, Türkiye Cumhuriyeti ve İnkılâp Tarihi gibi ders kitaplarında ayrı ayrı yerini almıştır.

1981 yılında Türkiye Cumhuriyeti ve İnkılâp Tarihi dersi, tarih dersinden ayrılarak bağımsız konuma getirilmiş ve adı "T.C. İnkılâp Tarihi ve Atatürkçülük" olmuştur. Çanakkale Savaşları konusu bu programın Giriş kısmında Osmanlı İmparatorluğu'nun dağılışı içindeki I. Dünya Savaşı alt başlığında yer almıştır. Burada ayraç içerisine şöyle uyarıcı bir yazı konmuştur: "(Özellikle Çanakkale Muharebeleri üzerinde önemle durulması)" "Çanakkale Savaşları, bu programda dolaylı olarak da ele alınmıştır. Örneğin Mustafa Kemal'in yaşamı anlatılırken, biraz önce değinilen uyarı burada da yinelenmiş ve konuyla ilgili olarak iki tane okuma parçası konulması istenmiştir ${ }^{6}$. Bunların yanı sıra, bu savaşlar yalnızca T.C. İnkılâp Tarihi ve Atatürkçülük dersinde değil, eskisi gibi lise tarih

${ }^{1}$ Utkan Kocatürk, Atatürk ve Türkiye Cumhuriyeti Tarihi Kronolojisi, 2. Baskı, Ankara 1988, s. 558-559.

${ }^{2}$ T.C. Maarif Vekaleti Milli Talim ve Terbiye Dairesi: 1340 Tarihli Orta Mektep ve Lise Müfredat Programlarına Zeyl, Devlet Matbaası, İstanbul 1927, s. 32.

${ }^{3}$ Tarih III, Yeni ve Yakan Zamanlar, 3. Basım, Ankara 1941, s. 307-308.

${ }^{4}$ Tebliğler Dergisi, 13 Eylül 1954, Sayı 816, s. 111; Tebliğler Dergisi, 7 Aralık 1959. Sayı 1086, s. 184; Tebliğler Dergisi, 27 Ocak 1974, Sayı 1824, s. 45; Tebliğler Dergisi, 27 Eylül 1976, Sayı 1900, s. 331

${ }^{5}$ Tebliğler Dergisi, 25 Mayıs 1981, Sayı 2087, s. 209.

${ }^{6}$ Tebliğler Dergisi, 25 Mayıs 1981, Sayı 2087, s. 209. 
programında da yerini korumuştur. Örneģin 1982 Tarih Dersi Geçici Müfredat Programı'nda üçüncü sınıflarda 4. ünitede "Osmanlı İmparatorluğunun Dağılması" başlığında I. Dünya Savaşı cephelerinde konu yer almış ve aynı durum 1983 lise tarih dersi programında da sürdürülerek hem bu savaşların hem de Mustafa Kemal'in başarıları üzerinde durulması gerektiği vurgulanmıştır ${ }^{7}$. Ders geçme ve kredili sistem için hazırlanan Tarih 1-2 Programı'nda da Çanakkale Savaşları'na yer verilmiştir ${ }^{8}$.

Müfredat Programları açısından Çanakkale Savaşları değerlendirilecek olunursa şunlar söylenebilir: Çanakkale Savaşları on bir yıl gibi kısa bir süre sonra tarih dersi müfredat programlarında yerini almış ve günümüze kadar yerini korumuştur. 1934 ve daha sonraki tarih müfredat programlarında Çanakkale Savaşları, tarih dersi müfredat programına ek olarak yapılan "Türkiye Cumhuriyeti ve İnkılâbı Tarihi" müfredat programı başlı̆̆ı içinde yerini almıştır. 1981 yılında ise tarih dersinden ayrı bağımsız olarak Türkiye Cumhuriyeti İnkılâp Tarihi ve Atatürkçülük adında yeni bir ders konulunca, Çanakkale Savaşları bu ders içinde yer almış ve üzerinde yoğunlaşılması istenmiştir. Yani, 1981 yılından başlayarak Çanakkale Savaşları, hem tarih, hem de Türkiye Cumhuriyeti İnkılâp Tarihi ve Atatürkçülük derslerinde doğrudan iki, Atatürk'ün yaşamı anlatılırken de dolaylı olarak bir defa olmak üzere toplam üç defa ele alınarak başarıya sahip çıkılmıştır. Konular, Mustafa Kemal ağırlıklı olmakla birlikte, programlarda gereğinden çok yer tutmuştur.

Konunun lise öğrenimi için yazılan ders kitaplarında olup-olmadığını, varsa hangi açılardan ele alındığını bilmek ve değerlendirebilmek için olayı aşağıda çizelgedeki gibi ele almakta yarar vardır. Çanakkale Savaşları'nın durumu değişik açılardan aşağıdaki çizelgedeki gibidir:

${ }^{7}$ Tebliğler Dergisi, 20 Aralık 1982. Sayı 2128, s. 487; Tebliğler Dergisi, 29 Ağustos 1983, Say1 2146, s. 342.

${ }_{8}^{8}$ Tebliğler Dergisi, 17 Ağustos 1992, Sayı 2364, s. 485. 


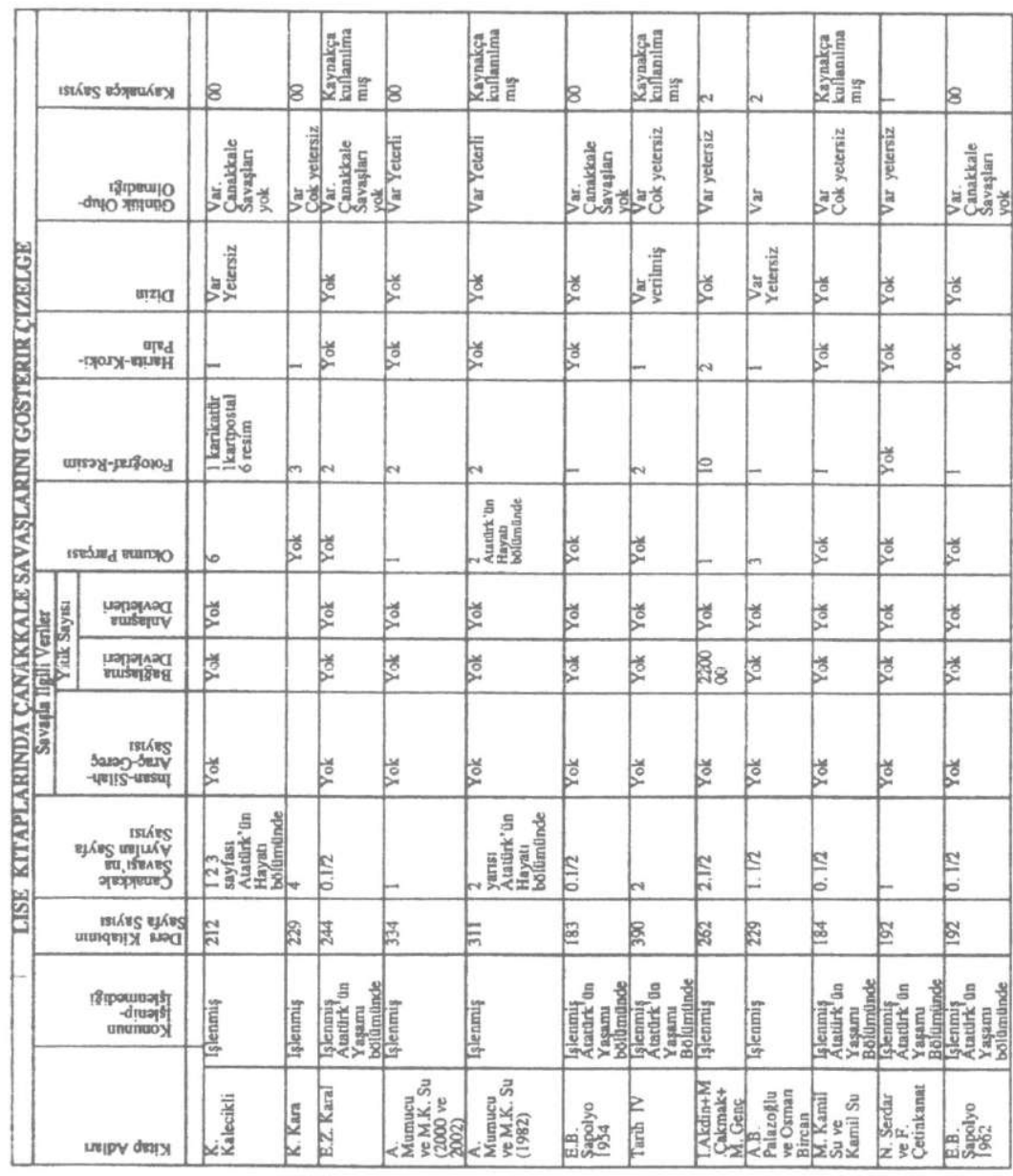

Konunun ele alınıp-alınmadığı, alındıysa nasıl işlendiği doğrultusuna bakıldığında, çizelgede görüldüğü ve daha önce değinildiği gibi, eski programa bağlı ders kitaplarında konu işlenmemiştir. Bunun nedenleri şunlardır: Birincisi ders konularının Mondros Ateşkes Antlaşması'ndan başlatılmasıdır. Çanakkale Savaşları Mondros'tan önce gerçekleştiği için doğal olarak konuya yer verilmemiştir. İkincisi konunun tarih kitaplarında yer alarak bu boşluğu bir ölçüde doldurması, üçüncüsü eskiden Çanakkale Savaşlarına bu kadar ilgi olmaması ve olayın değerinin bilinmemesi, dördüncüsü ise Türk toplumunun son yıllarda yurt içinde ve yurt dışındaki sıkıntılarından dolayı başarıyı özlemesi ve başarıları gündeme getirme gereği duymasıdır. Tarih IV yapıtında ve E. Ziya Karal ile Enver Behnan 
Șapolyo'nun yazdığı kitaplarda Çanakkale Savaşlarına doğrudan değinilmemiştir. Ortaya çıkan boşluğun birazı Mustafa Kemal'in yaşamı anlatılırken dolaylı yollardan doldurulmaya çalışılmıştır. Yani, bu savaşta Mustafa Kemal'in yaptıkları anlatılmıştır. Bu anlatımların hiç birinde savaşın nedenleri yoktur. Yalnızca Tarih IV'te İstanbul'un kurtarıldığına değinilerek sonuç verilmiştir. Yine bunlarda kompozisyon bütünlügü de bulunmamaktadır. Dolayısıyla Çanakkale Savaşları tam olarak verilememiştir.

Buna karşın, Mayıs 1981 yılı ve sonraki yıllarda liseler için düzenlenen müfredat programlarında Çanakkale Savaşları yer aldığından, bu doğrultuda yazılan Kemal Kara, Kenan Kalecikli, A. B. Palazoğlu+O. Bircan, A. Mumcu+M.K.Su ve İ.Akdin+M.Çakmak+ M. Genç'in kitaplarında konuya hem I. Dünya Savaşı'nda hem de Atatürk'ün Hayatı bölümünde yer verilmiştir. Bu kitaplardaki konunun işlenişi değerlendirilecek olunursa şu sonuçlar ortaya çıkacaktır: Bu kitapların anlatımları öncekilere göre daha iyidir. Dilleri genelde yalındır. Özellikle 1970'lerden başlayarak basılan kitaplarda kullanılan dil genelde lise öğrencilerinin düzeyindedir. Ancak konu bütünlüğünde Kemal Kara ve İ. Akdin ile arkadaşlarının yazdığ kitapların iyi olmasına karşın, diğerlerinde kompozisyon bütünlüğ̈ü yoktur. Tümünde anlatımlar 18 Mart Deniz Savaşı ve 25 Nisan kara çıkartmaları üzerine yoğunlaşmıştır. Hava ve denizaltı savaşları yoktur. Aslında Anlaşma Devletleri bu yöreden çekildikten sonra Mondros Ateşkes Antlaşması'na kadar savaşı havada sürdürmüşlerdir. Oysa tüm anlatımlar geri çekilmeyle bitirilmiştir. Burada da Mustafa Kemal odaklı bir anlatım söz konusudur. Kitaplarda savaşın nedenleri genelde Rusya'ya yardım yapılması olarak görüldüğü için, sonuçlarında da Rusya'ya yardım yapılamadığı ve orada düzen değişikliğinde etkili olduğu noktasında yoğunlaşılmıştır. Ayrıca bir kitapta sonuçlar daha baştan verilmiş, Kemal Kara ve İ. Akdinle arkadaşlarının yazdığı kitaplarda ise nedenler ve sonuçlar yeterli olarak anlatılmıştır. Savaşın sonuçlarının verilişinde bir özellik de genelde tek yanlı olması, yani, Osmanlılar açısından değerlendirilmesi ve bu sonuçların sonraki yıllardaki etkisine hiç değinilmemiş olmasıdır. Ayrıca savaşta barışçıl ve insancıl ilişkilerle, başarıların ve başarısızlıkların bulunmasına karşın, bunlar da anlatılmamıştır. Savaşla ilgili övgüler çoktur. Başarıya sahip çıkılarak adeta savaş kahramanlığı yapılmıştır. Eğer ölçü kahramanlıksa, karşı yanın da aynı düzeyde anlatılması gerekirdi. Karşı yanın anlatımında genelde İngilizler, Mustafa Kemal nedeniyle biraz da Anzaklar bulunmaktadır. Fransızlar ve beri taraftan Almanlar görmezlikten gelinmiştir. Yani, "Öteki" veya "Onlar" pek gözönünde bulundurulmadığı için, konu anlatımı yetersiz kalmış, UNESCO ve Avrupa Birliği'nin tarih anlayışına uymamıştır". Kısacası, 1981 yılından sonra oluşturulan

${ }^{9}$ Unesco'nun ve Avrupa Birliği'nin tarih anlayışına göre genel olarak şu özellikler, ilkeler veya ölçütler vardır; evrensellik, hukuka, kişiye ve farklılıklara saygı, karşılıklı güven, 
programlardaki “(Özellikle Çanakkale Muharebeleri üzerinde önemle durulması)" uyarısına yeterince uyulmamıştır.

Tarih eğitimi ışığında yapılması gereken şudur; Çanakkale Savaşı'nın genel bir tanımı yapılıp, nedenleri yazılmalı; olayın gerçekleşmesi ögrencinin anlayabileceği düzeyde ve içerikte verilmeli, bu yapılırken yalnızca 18 Mart Deniz Savaşı'ndan değil, oradaki kara, hava, lağım ve denizaltı savaşlarına da genel olarak değinilmelidir. Yine, savaşa her iki yan açısından bakılmalıdır. Konunun yalnızca savaş boyutu değil, insancıl ve barışçıl olayları da gündeme getirilmelidir. Olay ortaya konulduktan sonra, savaşın sonuçları, tarihteki yeri, önemi ve sonraki etkilerinden söz edilerek, başta Mustafa Kemal olmak üzere çok önemli komutanların savaştaki yerine kısaca değinilmelidir. Ayrıca, yapılabilirse, konunun yazıll metinleri savaşan yanlara karşılıklı inceletilerek onay alındıktan sonra yayımlatılmalıdır.

Ders kitaplarındaki Çanakkale Cephesi konusunun Osmanlının öteki cepheleriyle karşılaştırıldı ğında, konu olarak genelde Kafkas Cephesi'nden sonra ele alındığı görülmekle birlikte bazılarında en sona atılmıştır. Fakat en çok bu cepheye yer ayrılmıştır. Burada başarıya sahip çıkılmış, başarısızlıklar gözardı edilmiştir. "Biz" yani Osmanlılar vardır, "Öteki" yani Anlaşma Devletleri yetersizdir. Çoğu ders yapıtında duygusal davranılarak kahramanlıklara ve övgülere yer verilmiştir. Ancak bu yapılırken, karşı yan

barışı dostluğu ve kardeşliği savunma, kin duygularından arınma, kişileri, kurumları ve kültürleri aşağılamama, işbirliği yapma, propaganda yapmama, konuları çarpıtmama, ortak yaşamı veya geçmişi belirtme, Avrupa Birliği ülküsünü, Avrupa kültürünü ve İnsan Hakları Bildirgesini benimseme, hümanist olma, demokrasiyi temel değer alma, ön yargilardan veya peşin hükümlülüklerden kaçınma, yansızlık, doğruluk, dürüstlük, hakkaniyetlik, ulusların birbirlerine katkılarının belirtilmesi, gençlerde yanlış izlenim bırakmama, soyları başka soylara zarar verecek biçimde övmeme ve yermeme, şovenizme varacak biçimde milliyetçilikten kaçınma ve şovenist olmayacak biçimde yurtsever olma, yazarın gerçekçi ve yansız olması, kavramların açık olması, güncellik, yayınevleri ya da kitapların basım haklarını ellerinde tutanların da sorumlu olması ve tarihi kötüye kullanmama" ...gibi. Daha çok bilgi için aşağıdaki kitaplara bakınız: Koullapıs Lory Gregory, "Türkiye'de Tarih Ders Kitapları ve UNESCO'nun Önerileri”, Tarih Ögretimi ve Ders Kitapları, Haz: Salih Özbaran, İzmir 1998.

Laurent Wirth, "Tarihi Kötüye Kullanma Biçimleriyle Yüzleşmek", Tarihi Kötüye Kullanma Biçimleriyle Yüzleşmek Sempozyumu, Oslo, Norveç/ 28-30 Haziran 1999, Çev: Nurettin Elhüseyni, 2. Baskı, İstanbul 2004.

Pingel Falk, Ders Kitaplarını Araştırma ve Düzeltme Rehberi, Çev: Nurettin Elhüseyni, İkinci Baskı, İstanbul 2004.

Schueddekopf Otto-Ernst, Edouar Bruley, E.H. Dance, Haakon Vigander, Tarih Ögretimi ve Tarih Kitaplarının Geliştirilmesi, Çev: Necati Engę, İstanbul 1969.

Stradlıng Robert, "20. Yüzyıl Avrupa Tarihi Nasıl Ögretilmeli?", Tarih Eğitimine Eleştirel Yaklaşımlar, Avrupalt-Türkiyeli Tarih Eğitimcileri Buluşması Ekim 2001-Kasım 2002, Yayıma Haz: Oya Köymen, İstanbul 2003.

Tarih Eğitimine Eleştirel Yaklaşımlar, Avrupalı-Türkiyeli Tarih Eğitimcileri Buluşması Ekim 2001-Kasım 2002, Yayıma Haz: Oya Köymen, İstanbul 2003.

Tarih Ögretiminde Çoğulcu ve Hoşgörülü Bir Yaklaşıma Doğru, 10-12 Aralık 1998 tarihinde Brüksel/Belçika da düzenlenen sempozyum, Yayıma Haz: Özgür Sevgi Göral, Istanbul 2003. 
pek incitilmemiş, küçük düşürülmemiş ve onlara hakaret edilmemiştir. Yalnız Tarih IV kitabında, Kemal Kara, Ahmet Mumcu+M. Kamil Su'nun yazdığı kitaplarda ötekiler için "DÜŞMAN" sözcügüu kullanılmıştır ${ }^{10}$. Bu sözcük kaldırılarak yerine "karşı taraf" denilebilirdi ya da düşman sözcüğü vurgulanmak isteniyorsa, "o günkü düşman, savaş sırasındaki düşman" gibi sözcüklerle süre sınırlandırılarak olay yumuşatılabilirdi. Burada ilginç olan son yıllarda basılan ders kitaplarında Kenan Kalecikli dışında bu sözcüğün kullanılmamasıdır ${ }^{11}$. Bu da ders kitapları yazılımının iyiye gittiğini göstermektedir. Ayrıca Kenan Kalecikli "komutanlarımızın, askerlerimizin" diyerek konunun anlatımıyla kendisini özdeşleştirerek yanlı duruma düşmüștür ${ }^{12}$. $\mathrm{Bu}$ durumlar da UNESCO ve Avrupa Birliği'nin tarih anlayışına biraz uymamaktadır. Bundan sonra ders kitabı yazacakların bu durumu göz önünde bulundurması gerekir.

Ders kitaplarının sayfa sayıları, çizelgede görüldüğü gibi, çok değişiktir. $\mathrm{Bu}$ durum ders kitabının basıldığ 1 yıllardan, programlardan ve yazarın/yazarların tutumundan kaynaklanmaktadır. Yazının içeriği bu olmadığ 1 için bu konuda yorum yapmak uygun olmayacaktır. Ancak Çanakkale Savaşlarına ayrılan sayfa sayısına bakıldığında eleştirilecek yanı çoktur. Çünkü bazı kitaplar konuyu doğrudan işlemeyip, "Atatürk'ün Yaşamında" ve okuma parçalarında yer vermişlerdir. Doğrudan işleyenler de yetersiz yer ayırmışlardır. Yüzdeye vurulursa, \% 2 dolayındadır. Üstelik, 1981 yılından sonra bu ders tarih dersinden bağımsızlaştırıldığı gibi, haftada dört saate çıkartılmıştır ${ }^{13}$. Önemli bir savaş için bu oran yetersiz kalmıştır. $\mathrm{Bu}$ durumun yeni baskılarda gözden geçirilmesi, yeni ders kitabı yazacakların da bu durumu gözönünde bulundurmaları gerekir.

Ders kitaplarına savaşa katılan insan, silah, araç ve gereç yönünden bakıldığında, tümünde sayısal verilerin olmadığı görülmektedir. Bu konuda çok genel olarak sayısal bilgiler verilebilirdi.

Bu savaşların anlatımında önemli olumsuz yanlardan biri de, yitirilen insan sayısı verilerinin İ. Akdin ve arkadaşlarınca yazılan kitabın dışındakilerce verilmemiş olmasıdır. Adı geçen yazarlar 220000 sayısını kullanmışlardır. Aslında bu sayı yanlıştır. Türkiye Cumhuriyeti Milli Savunma B̉akanlı̆̆ı'na göre bu sayı 155 000'i İngiliz, 25 000'i Fransız olmak üzere Anlaşma Devletleri'nin 180 000, Osmanlı Devleti'nin ise 57

${ }^{10}$ Tarih IV, Türkiye Cumhuriyeti Tarihi, Ankara 1941, s. 22: Kara, K., Türkive Cumhuriyeti İnkılâp Tarihi ve Atatürkçülük, İstanbul 1999, s. 29; Mumcu, A., Su, M.K., Türkiye Cumhuriyeti İnklâp Tarihi ve Atatürkçülük, 4. Baskı, İstanbul 2000, s. 29. $21-22,59$

Kalecikli, K., Türkiye Cumhuriyeti İnkılâp Tarihi ve Atatürkçülü̈k i, İstanbul 1994, s. 60 .

${ }_{12}$ Kalecikli, K., Türkiye Cumhuriyeti İnkalâp Tarihi ve Atatürkçülük 1, İstanbul 1994, s.

${ }_{13}^{13}$ Tebliğler Dergisi, 25 Mayıs 1981, Sayı 2087, s. 209; Tebliğler Dergisi, 14 Eylül 1981, Say1 2095, s. 305-306. 
263 'tür ${ }^{14}$. Ancak ulaşılamayan, ulaşılıp da şimdilik yayınlanamayan bazı verilerin daha olduğu gözönüne getirilirse, bu yitik sayısı biraz daha yükselebilir. Bilgi türünden de olsa sayıların genel olarak verilmesi uygun olacaktır. Bundan böyle ders kitabı yazacakların ve yeni baskı yapacakların bu konuyu göz önünde bulundurması gerekecektir. Sonuçların verilmesinde İ. Akdin+M.Çakmak+ M. Genç'in kitabında çok önemli bir yanlışlık da şudur: Bu savaşta 100 000'den çok öğretmen ve mülkiyeli okumuş insan öldüğ̈unün yazılmasıdır. Yani 220000 yitik verildiğini ileri süren yazarlara göre, neredeyse ölenlerin yarısı eğitimli insanlardır. Bu görüş tümden yanlıştır. Çünkü 1927 yılı nüfus sayımına göre Türkiye'de okuma yazma oranı \% $7.5^{\prime}$ tur $^{15}$. Burada olsa olsa bunun birkaç puan daha yukarısında olabilir. Yeni basımlarda bu yanlışın da düzeltilmesi gerekir.

Ders kitaplarında okuma parçalarına gelince, öğrencilerin ilgisini çekmek ve farklı açılardan yararlanabilmelerini sağlamak amacıyla okuma parçalarının konulması gerekir. Ancak, eski programdaki kitaplar, okuma parçalarına yer vermemiştir. Yenilerde vardır, fakat onların da bir bölümü iki okuma parçası konulması uyarısına uymamıştır. Bazıları ikiden çok okuma parçasına yer vermiştir. Aslında, neden iki tane okuma parçasının konulması gerektiği de tartışılabilir. Okuma parçasında bir sıkıntı da, lise ile yükseköğrenimdeki ders kitaplarında aynı okuma parçalarının sıkça bulunmasıdır. Okuma parçası konulacaksa, yükseköğretimdeki bu ders kitaplarıyla eşgüdüm içerisinde olunmalıdır. Çünkü çoğu zaman aynı okuma parçaları her iki tür kitaplarda basıldığından bu durum sıkıcılığı getirdiği gibi, amaca da ulaşamamakta ve yaprak savurganlığına neden olmaktadır.

Çağımızda eğitimde görsellik önem kazanmaya başlamıştır. Görsellik insan belleğinde uzun süre yer etmekte, derste sıkıcılığı önlemekte, bazen de sayfalarca yazıdan daha anlamlı olabilmektedir. Bu açıdan ders kitaplarına bakıldığında, fotoğraf, resim, karikatür, harita, kroki ve plân gibi görsel verilerin yetersiz de olsa kullanıldığı görülmektedir. Bu yönde $\mathrm{K}$. Kalecikli ile İ.Akdin+M.Çakmak+ M. Genç görsellikten iyi yararlanmışlardır. Hatta şehitliklerin günümüzdeki fotoğrafları bile konulmuştur. Kitaplarda fotoğraflar genelde güzeldir, ancak E. Ziya Karal, fotoğrafı konudan bir sayfa sonraki ilgisiz yere koymuştur. Ahmet Mumcu ile M. Kamil Su, yazdıkları ders kitabının eski ve yeni basımlarında aynı fotoğrafları kullanmışlardır. 1981 yılı basımının siyah-beyaz fotoğrafları daha güzeldir. Son basımlarında bir tanesini renklendirmişlerdir. Bu renklendirme işi birkaç kitapta daha vardır. Ancak bazılarının albenisi olmadığ durmaktadırlar. Buna da özen gösterilmelidir. Ayrıca görsellik Mustafa

${ }_{14}^{14}$ Sehitlerimiz, Haz:Türkiye Cumhuriyeti Milli Savunma Bakanlığı, Ankara 1998, s. 40.

15 Maarif İstatistikleri 1923-1932, Haz: Başvekalet İstatistik Umum Müdürlüğu. Ankara 1933, s. 2; Maarif İstatistiği 1941-1942, Haz: Başvekalet İstatistik Umum Müdürlüğü, Ankara 1944, s. XI. 
Kemal'in fotoğraflarına odaklanmıştır. Bu durum doğaldır. Burada ilgimizi çeken resimlerin savaş ağırlıklı olmasıdır. Barışa, işbirliğine ve dostluğa yönelik görsellik azdır. Oysa son yıllarda Çanakkale'deki toplantılarda barı̧̧ ağırlıklı iletiler verilmektedir. Konuyla ilgili görsellikler çeşitlendirilmelidir. Özellikle son yıllarda bu savaşla ve savaş alanlarıyla ilgili çok sayıda değişik özgün fotoğraflar yayımlanmıştır. Bunlar içinde barışa katkıda bulunacak, insanları ve ulusları birbirine yaklaştırabilecek fotoğraflar vardır. Hatta lise ögrencileri yaşında asker fotoğrafları bulunduğu gibi, savaşın olumsuzluklarını, insanlığa ve çevreye verdiği zararları gösterenler de bulunmaktadır. Bunlardan yararlanılabilir. Görsellikte bir eksiklik de resim ve fotoğrafların sayfalara yanlış biçimde yerleştirilmesidir. Birkaç kitapta görsel veriler paragrafları hatta tümceleri bölmüştür. Bu da ögrencinin okuyup anlamasına olumsuz etki edecektir. Kısacası, bunların eğitime uygun olanlarından örnekler seçilip, ders kitaplarına konulabilir. Yine savaş yöresini genel olarak içeren ve savaşan yanların güçlerinin nerelerde olduğunu gösteren bir haritanın verilmesinde yarar olacaktır. Bu konuda karikatürlerden de yararlanılabilir.

$\mathrm{Bu}$ kitapların çoğunluğunda dizin (indeks) yoktur, olanlar da yetersizdir. Oysa dizin önemlidir. İnsanlar ne istediklerini dizine bakarak bir anda bulabilirler. Bu durum insanlara süre kazandırdı̆̆ kitaplarının yıpranmasının önlenmesine de yardımcı olur. Ayrıca lisedeki bir öğrenciye bu yönde bir davranı̧ kazandırabilir. Bunlardan dolayı bundan sonra ders kitabı yazacak yazarların dizin koymasında ve konulacak dizinde bu savaşlara yer vermesinde yarar olacaktır.

Günlük de dizin gibi ögrencinin aradığını bir anda bulmasına yardımeı olur. Öğrenci tüm kitabı incelemektense, günlüğe bakarak aradığını kolayca bulabilir. Böylece süreden kazandığ ${ }_{1}$ gibi, kitabın sayfaları da daha az yıpranmış olur. Bu davranış biçimine dönüştürebilirse, insan yaşamı kolaylaştırılır. Ders kitaplarının tümü günlük açısından değerlendirildiğinde aşağıdaki gibidir:

18 Mart 1915, İngiliz-Fransız donanmalarının Çanakkale Boğazını geçmeye çalışmaları ve Türk Zaferi (Çanakkale Deniz Zaferi) ${ }^{16}$.

25 Nisan 1915, İngilizlerin Arıburnu'na Asker çıkarması (Arıburnu'na çıan İtilaf Devletleri'nin askerlerinin Mustafa Kemal tarafından durdurulmasi) ${ }^{17}$.

${ }^{16}$ K. Kara, age., s. 224; A. Mumcu+M. K. Su 1981 age, s. 294; A. Mumcu+M. K. Su 2000 age., s. 308; Akdin, İ., Cakmak, M., Genc, M.,Türkiye Cumhuriyeti Ínkılâp Tarihi ve Atatürkçülük Lise 3, Birinci Baskı, İstanbul 2005, s. 257; N. Serdarlar+ F. Çetinkanat, Türkiye Cumhuriyeti Tarihi, İstanbul 1972, s. 187; Palazoğlu, A.B., Bircan, O., Ders geçme ve kredi sistemine göre Türkive Cumhuriveti Inkılâp Tarihi ve Atatürkçülük 1, ?, s. 218 bu yazarlar bu tarihi yanlı̧̧ olarak 19 Şubat 1915 göstermişlerdir.

${ }^{17}$ K. Kara, age., s. 224; A. Mumcu+M. K. Su:1981 age., s. 294; A. Mumcu+M. K. Su: 2000, age., s. 308; I.Akdin+M.Cakmak+ M. Genç, age., s. 257: A.B. Palazoğlu+ O. Bircan, age., s. 218; N. Serdarlar+ F. Çetinkanat, age., s. 187. 
8 Mayis 1915, Anafartalar Muharebesi ${ }^{18}$.

6-7 Ağustos 1915, M. Kemal'in Anafartalarda İngiliz ve Fransızlara galebesi ${ }^{19}$.

8-9 Ağustos 1915, Mustafa Kemal'in Anafartalar Grup Komutanlı̆̆ı'na atanmass ${ }^{20}$.

21 Ağustos 1915, Mustafa Kemal'in II. Anafartalar Savaşı'nı
kazanmasi $^{21}$.

1916, İngilizlerin Gelibolu Yarımadası'nı boşaltması ${ }^{22}$.

9 Ocak 1916, İtilaf Donanmasının gizlice Çanakkale Boğazı'nı terketmesi ${ }^{23}$.

Yukarıdaki çizelgede ve verilerde görüldüğü gibi, günlük (kronoloji) yapıtların bir bölümünde vardır. Ancak var olanların çoğunluğunda yetersizdir. Burada şunu belirtmekte yarar olacaktır; yukarıda verilen günlük bir ders kitabını kapsamayıp, tümünün toplamıdır. Dolayısıyla tek tek bir ders kitabı açısından bakıldığında, günlük verilişinin yetersiz olduğu görülmektedir. Bundan böyle yazılacak ders kitaplarında önemli tarihler verilirse iyi olur.

Kaynakça, ders kitabını yazan yazar/yazarların ve kitapların güvenirliğini ölçer. Öğrenciyi ilgili kaynaklara yönlendirir. Ders kitaplarına kaynakça açısından bakıldığında, bunun da günlük gibi kısır olduğu görülmektedir. Kaynakçalar aşağıdaki gibidir:

Birinci Dünya Harbinde Türk Harb ve Çanakkale Cephesi Haz: Genelkurmay Başkanlığı, Ankara $1993^{24}$.

İlhan Akşit, Çanakkale Savaşları, İstanbul 1973²5.

Cevat Abbas Gürer, "Cevat Abbas Gürer'den bazı hatıralar", Yakınlarından hatıralar, İstanbul $1955^{26}$.

Ruşen Eşref Ünaydın, Anafartalar Kahramanı Mustafa Kemal ile Mülakat, İstanbul $1930^{27}$.

${ }^{18}$ A. Mumcu+M. K. Su 1981 age., s. 294; A. Mumcu+M. K. Su 2000 age., s. 308.

27.

${ }^{19}$ Tarih IV, age., s. 359; Su, M.K., Su, K., Türkiye Cumhuriyeti Tarihi, İstanbul 1971, s.

${ }^{20}$ I.Akdin+M.Çakmak+ M. Genç, age., s. 257.

${ }^{21}$ I.Akdin+M.Çakmak+ M. Genç, age., s. 257.

${ }^{22}$ A. Mumcu+M. K. Su 1981 age., s. 294; A. Mumcu+M. K. Su 2000 age., s. 308.

${ }_{23}^{23}$ A.B. Palazoğlu+ O. Bircan, age., s. 218 .

${ }^{24}$ I.Akdin+M.C.akmak+ M. Genç, age., s. 260.

${ }^{25}$ i. Akdin+M.Çakmak+ M. Genç, age., s. 260

26 A.B. Palazoğlu+ O. Bircan, age, s. 224.

${ }^{27}$ A.B. Palazoğlu+ O. Bircan, age, s. 225 
Ders kitaplarında dolaylı kaynakçalar daha yoğunlukta kullanılmıştır. Örneğin; Atatürk, Atatürk'ün Yaşamı, Tek Adam, Atatürk'ün Askeri Kişiliği, I. Dünya Savaşı ... gibi kitaplar bunlar arasındadır.

Kaynakça açısından bir değerlendirme yapılacak olunursa şu sonuç ortaya çıkar: Yazarlar bu savaşlarla ilgili olarak temel kaynaklara inememişlerdir. İnenler de yetersizdir. Konuyu doğrudan işlemediği halde kaynak belirtenler olduğu gibi, tam karşıtı olarak konuyu işlediği halde kaynak belirtmeyenler de vardır. Bunların niçin kaynak gösterdikleri ya da göstermedikleri, neye dayanarak konuyu yazdıkları belli değildir. Yine, son yıllarda yeni birçok kitap yazılmıştır. Bu son yılların kaynakları da yer almamıştır. Ayrıca, yazarlar yabancı kaynaktan hiç yararlanmamışlardır. Konuyu tek yanlı kaynaktan anlatmaya çalışmışlardır. Karşı yanın ne düşündüğünü merak etmemişlerdir. Bu olumsuzlukların da giderilmesi gerekir.

Konuya soru sorma açısından bakıldığında, bu yönden de yetersiz kaldığı görülmektedir. Eski programlara göre basılan kitaplarda soru hiç yoktur. Yenilerde de araştırma sorusu yoktur. Bu büyük bir noksanlıktır. Yani, yazarlar veya kitapları, öğrencileri konuya hazırlayamamaktadır. Öğrenciler, konuya hazır bulunmuşluk düzeyi bakımından yetersiz gireceklerdir. Bu da öğrencilerin ve öğretmenin başarısına olumsuz etki edecektir.

Ders kitaplarındaki değerlendirme soruları şunlardır:

"Çanakkale cephesi hangi nedenlerden açılmıştır?"

"Çanakkale zaferinin ne gibi önemli sonuçları olmuştur??",

"Çanakkale Savaşı'nın sebep ve sonuçlarını açıklayınız ${ }^{30}$."

"Çanakkale Zaferi Mustafa Kemal'in hangi yönünü ortaya çıkarmıştır? ?",

“Mustafa Kemal, Çanakkale Cephesi'nde Türk ordusuna hangi emri vermiştir? $?^{32}$,

"Çanakkale Savaşlarının sonuçlarını açıklayınız ${ }^{33}$."

“Atatürk'ün Anafartalar Zaferini nerede, ne zaman ve kimlere karşı kazandığını, bu zaferin Türkler ve düşmanlar bakımından ne gibi sonuçlar doğurduğunu söyleyiniz ${ }^{34}$."

\footnotetext{
${ }^{28}$ K. Kara, age., s. 33

${ }^{29} \mathrm{~K}$. Kara, age., s. 33.

${ }^{30}$ I. Akdin+M.Çakmak+ M. Genç, age., s. 20.

${ }^{31}$ I.Akdin+M.Cakmak+ M. Genç. age., s. 20.

${ }^{32}$ I.Akdin+M.Çakmak+ M. Genç, age., s. 20.

${ }^{33}$ A.B. Palazoğlu+O. Bircan, age., s. 21.

${ }^{34}$ M.K. Su+A.Mumcu: 1981 age., s. 54.
} 
Dolaylı sorular da vardır. Örneğin;

"Osmanlı
savaşmıştır?", Devleti Birinci Dünya Savaşı'nda hangi cephelerde

“Birinci Dünya Savaşı'nda Osmanlı Devleti'nin savaştığı cephelerin adlarını ve hangi devletlerle savaştığını açıklayınız ${ }^{36}$."

"Birinci Dünya Savaşında Atatürk hangi görevlerde bulundu ve bu görevlerde ne gibi başarılar sağladı? ?", $^{37}$

"Osmanlı Devletinin Birinci Dünya Savaşına nasıl katıldığını, hangi cephelerde çarpışığını ve bu çarpışmaların nasıl sonuçlandığını anlatınız $z^{38}$."

“Atatürk'ün Birinci Dünya Savaşında hangi cephelerde görev aldığını ve hangi muharebeleri yönettiğini, rütbesinin generalliğe ne zaman yükseltildiğini yazınız ${ }^{39}$."

Görüldüğü gibi çoğu yazar konuyla ilgili olarak soru sormamıştır. Birkaç soru çift şıklıdır. Tek bir kitap açısından bakıldığında hiç birinin soruları konuyu tam olarak kapsamamaktadır. Yani kapsam geçerliliği yoktur. Ancak İdris Akdin'in “Mustafa Kemal, Çanakkale Cephesi'nde Türk ordusuna hangi emri vermiştir?" sorusu dişındaki sorular iyidir. Yorum olduğu için lise ögrencilerinin düzeyine uygundur.

Bu soruların bir noksanlığı "yazınız, açıklayınız, belirtiniz, tartışınız" gibi soruları yönlendirici veya tamamlayıcı kavramların olmamasıdır. Öğrencinin burada sorularla ilgili olarak ne yapacağ 1 belli değildir. Öğrencilerin konuyu pekiştirmesi açısından değerlendirme sorularına daha özen gösterilmelidir.

Son yıllarda birçok ders kitabı üniversiteye giriş için çoktan seçmeli sorulara yönelmiştir. Tarih ders kitabı yazarları da kendini bundan alıkoyamamışlardır. Dolayısıyla onlardan da yalnızca İdris Akdin ve arkadaşlarınca yazılan kitapta vardır. Onların dışındakilerde test sorusu sorulmamıştır. İdris Akdin ve arkadaşlarınca yazılan kitapta yer alan konuyla ilgili çoktan seçmeli sorular şunlardır:

1- Aşağıdaki seçeneklerin hangisinde, I. Dünya Savaşı'nın uzamasında en etkili olan cephe verilmiştir? ${ }^{40}$

A) Kafkas Cephesi

\footnotetext{
${ }^{35}$ K. Kalecikli, age., s. 32 .

${ }_{36}$ A.B. Palazoğlu+O. Bircan, age., s. 21.

${ }^{37}$ M.K. Su+K. Su. age., s. 26.

${ }^{38}$ M.K. Su+A. Mumcu: 1981 age., s. 18.

${ }^{39}$ M.K. Su+A.Mumcu: 1981 age., s. 54.

${ }^{40}$ I.Akdin+M.Çakmak+ M. Genç, age., s. 21 .
} 
B) Çanakkale Cephesi

C) Suriye Cephesi

D) Makedonya Cephesi

E) Irak Cephesi

YANIT : B

2- Mustafa Kemal Çanakkale Savaşları sonunda hangi rütbeye terfi etmiştir?
A) Albay
B) Binbaşı
C) Kurmay Yüzbaşı
D) Kıdemli Yüzbaşı
E) General

YANIT: A

Çanakkale Savaşları konusu test sorusuna uygundur. Konuyla ilgili olarak birkaç soru çıkartılabilirdi. Kısacası, öğrenciyi konuya hazırlayabilmek için yazarların konuyla ilgili olarak hazırlık soruları koyması gerekir. Değerlendirme ve test soruları da konuyu kapsayacak biçimde öğrenci düzeyine uygun olarak seçilip konulmalıdır.

Sonuç olarak denilebilir ki; Çanakkale Savaşları gerek Osmanlı, gerek Türkiye Cumhuriyeti, gerekse Dünya Tarihi bakımından önemlidir. Bu nedenle, gençliğin çoğunluğunun lise öğrenimi gördüğü de düşünüldüğünde, liselerdeki ders kitaplarında Çanakkale Savaşları konusunun daha düzenli yazılması gerekir. Konu hem tarih kitaplarında hem de Türkiye Cumhuriyeti İnkılâp Tarihi ve Atatürkçülük kitaplarında ayrı ayrı yer almamalıdır. Konu yalnızca Türkiye Cumhuriyeti İnkılâp Tarihi ve Atatürkçülük adlı ders kitabında ve yukarıda değinilen yanlışlıklar ve eksiklikler giderilerek yer almalıdır.

\section{INCELENEN DERS KITTAPLARI}

Akdin, İ., Çakmak, M., Genç, M., Türkiye Cumhuriyeti Inkılâp Tarihi ve Atatürkçülük, Lise 3, Birinci Baskı, İstanbul, 2005.

Kafesoğlu, İ., Saray, M., Atatürk İlkeleri ve Dayandığı Temeller, İstanbul, 1985.

Kalecikli, K., Türkiye Cumhuriyeti İnkılâp Tarihi ve Atatürkçülük 1, İstanbul, 1994.

Kara, K., Türkiye Cumhuriyeti İnkllâp Tarihi ve Atatürkçülük, İstanbul, 1999. 
LISELERDE OKUTULAN TÜRKIYE CUMHURIYETI VE ATATÜRKÇÜLÜK .... 721

Karal, E.Z., Türkiye Cumhuriyeti Tarihi 1918-1965, TTK basımı, Ankara, 1981.

Mumcu, A., Su, M.K., Türkiye Cumhuriyeti İnkılâp Tarihi, Birinci Basılış, İstanbul, 1981.

Mumcu, A., Su, M.K., Türkiye Cumhuriyeti Inkılâp Tarihi, 2. Baskı, İstanbul, 1982.

Mumcu, A., Su, M.K., Türkiye Cumhuriyeti Inkılâp Tarihi ve Atatürkçülük, 4. Baskı, İstanbul, 2000.

Serdarlar, N., Çetinkanat, F., Türkiye Cumhuriyeti Tarihi, İstanbul,1972.

Palazoğlu, A.B., Bircan, O., Ders Geçme ve Kredi Sistemine Göre Türkiye Cumhuriyeti İnkılâp Tarihi ve Atatürkçülük 1, ?.

Su, M.K., Su, K., Türkiye Cumhuriyeti Tarihi, İstanbul, 1971.

Şapolyo, E.B., Türkiye Cumhuriyeti Tarihi, İstanbul, 1968.

Tarih IV, Türkiye Cumhuriyeti Tarihi, Ankara, 1941.

\section{KAYNAKÇA}

Maarif Istatistikleri 1923-1932, Haz: Başvekalet İstatistik Umum Müdürlügü, Ankara, 1933.

Maarif İstatistiği 1941-1942, Haz: Başvekalet İstatistik Umum Müdürlüğü, Ankara, 1944.

Şehitlerimiz, Haz:Türkiye Cumhuriyeti Milli Savunma Bakanlı̆̆ı, Ankara, 1998.

Utkan Kocatürk, Atatürk ve Türkiye Cumhuriyeti Tarihi Kronolojisi, 2. Baskı, Ankara, 1988.

Tarih III, Yeni ve Yakın Zamanlar, 3. Basım, Ankara, 1941.

Tebliğler Dergisi, 13 Eylül 1954, Sayı: 816.

Tebliğler Dergisi, 07 Aralık 1959, Sayı: 1086.

Tebliğler Dergisi, 27 Ocak 1974, Sayı: 1824.

Tebliğler Dergisi, 27 Eylül 1976, Sayı: 1900.

Tebliğler Dergisi, 25 Mayıs 1981, Sayı: 2087.

Tebliğler Dergisi, 29 Ağustos 1983, Sayı: 2146.

Tebliğler Dergisi, 17 Ağustos 1992, Sayı:2364.

T.C. Maarif Vekaleti Milli Talim ve Terbiye Dairesi: 1340 Tarihli Orta Mektep ve Lise Müfredat Programlarına Zeyl, Devlet Matbaası, İstanbul, 1927. 